\title{
Morpho-meristics, maturity stages, GSI and gonadal hormone plasticity of African catfish Clarias gariepinus (Burchell 1822) that invaded into the Ganga River, India
}

\author{
Atul K. Singh ${ }^{*}$ (D, Abubakar Ansari and Sharad C. Srivastava
}

\begin{abstract}
Background: African catfish Clarias gariepinus introduced to India has gravitated into the Ganga River as an invasive species. Morphological plasticity and reproductive adaptation are considered and reported as important manifestation contributing to evolution and persistence of an invasive species in the novel environment facilitating its expansion and establishment. African catfish in the Ganga River although documented to exist, it is yet to investigate if it elicits adaptation responses through morphological and reproductive plasticity in the riverine conditions. Therefore, morpho-meristic changes, plasticity in the reproductive stages, gonadosomatic index (GSI) and gonadal hormones were examined in C. gariepinus that invaded into the Ganga River so as to ascertain its invasion success.

Results: Out of 23 morpho-meristic characters examined, head length (HL), head depth (HD), anal fin length (AFL) and the pectoral fin rays (PECFR) were observed to differ significantly $(p<0.05)$. The correlation coefficient ' $r$ ' between log length and log weight was found to be 0.9690 in culture and 0.8754 in river-caught specimens respectively. A distinct deviation in the maturity stages, GSI as well as gonadal hormones (testosterone, estradiol 17- $\beta$ and vitellogenin) was further observed to change significantly in specimens of African catfish captured from the Ganga River as compared to those available in culture. Highest level of testosterone was found in males having gonadal stage $V$ which was $184.82 \pm 10.4 \mathrm{pg} / \mathrm{ml}$ in culture and $204.82 \pm 21.34 \mathrm{pg} / \mathrm{ml}$ in river-captured specimens. The mean value of serum estradiol- $17 \beta$ was lowest $(67.25 \pm 11.4 \mathrm{pg} / \mathrm{ml})$ in gonadal maturity stage I and highest $(328.73 \pm 24.5 \mathrm{pg} / \mathrm{ml})$ in stage $\mathrm{V}$ in the river-captured C. gariepinus. The vitellogenin level in female C. gariepinus was detected in stage III, and it was maximum in stage $V$ where it was $16.68 \pm 2.98 \mathrm{pg} / \mathrm{ml}$ in rivercaptured specimens and $12.63 \pm 2.12 \mathrm{pg} / \mathrm{ml}$ in cultured fish.

Conclusion: The results of this study on morpho-meristic and gonadal plasticity provide first evidence of invasion success of the African catfish gravitated in the Ganga River which has now adapted to the river environments for breeding and establishing. The variations concerning different reproductive phases and the gonadal hormones in culture and river-caught C. gariepinus have been considered to contribute to the success of the colonisation and establishment. The knowledge generated on the phenotypic and reproductive plasticity of African catfish available in the Ganga River will help management and control programmes.
\end{abstract}

Keywords: African catfish, Morpho-meristics, Reproduction, Invasion, Gonadal hormones

\footnotetext{
* Correspondence: aksingh56@rediffmail.com

National Bureau of Fish Genetic Resources, Canal Ring Road P.O. Dilkusha, Lucknow, Uttar Pradesh 226002, India
}

\section{Springer Open}

(C) The Author(s). 2021 Open Access This article is licensed under a Creative Commons Attribution 4.0 International License, which permits use, sharing, adaptation, distribution and reproduction in any medium or format, as long as you give appropriate credit to the original author(s) and the source, provide a link to the Creative Commons licence, and indicate if changes were made. The images or other third party material in this article are included in the article's Creative Commons licence, unless indicated otherwise in a credit line to the material. If material is not included in the article's Creative Commons licence and your intended use is not permitted by statutory regulation or exceeds the permitted use, you will need to obtain permission directly from the copyright holder. To view a copy of this licence, visit http://creativecommons.org/licenses/by/4.0/. 


\section{Background}

The African catfish Clarias gariepinus is highly domesticated cultured freshwater fish forming stable populations worldwide (FAO, 2016). It is native to most of Africa and has been introduced to over 37 countries including India mainly for aquaculture. The fish was unofficially introduced to India possibly during 1996 when aquaculturists got attracted to culture it because it grew fast accepting a wide range of cheap feed (Singh \& Lakra, 2011). The fish soon spread into the entire country even in harsh environmental conditions and was found as a good scavenger as it takes slaughterhouse wastes and even fish wastes as feed (Singh, Srivastava, Ansari, Kumar, \& Singh, 2012). The introduced non-native African catfish intentionally or accidently escaped from aquaculture facility and gravitated into the rivers and reservoirs of different states in India (Krishnakumar, Ali, Pereira, \& Raghavan, 2011; Madhusoodanan, Prasannan, Smrithy, \& Biju Kumar, 2016; Singh et al., 2013; Singh \& Lakra, 2011). In fact, it is now available in several large natural water bodies such as the Ganga, Yamuna, Sutlej and Godavari rivers and backwaters of coastal areas (Krishnakumar et al., 2011; Ranjan, 2018; Singh, 2014; Singh et al., 2013).

The mid-stream of the Ganga River supports commercial fishery to the fisherfolk and contributes significant economic benefits to the riparian communities and the national economy (Das et al., 2013). The river holds a copious biological wealth, characterised by its rich faunistic diversity including endemism (Sarkar, Dubey, Singh, \& Singh, 2017). In recent time, the Ganga River is invaded by many non-native fishes which are now contributing substantially to its fishery (Singh et al., 2013; Singh \& Lakra, 2011). Any invasion in the river has a series of processes, i.e. transport, introduction, establishment and spread (Blackburn et al., 2011; Gu et al., 2017; Singh \& Lakra, 2011), each of which is confounded by barriers such as geography, captivity, survival, reproduction, dispersal and environment that need to be overcome before passing on to the next invasion stage.

The introduction of an exotic species into a nonnative habitat provides the opportunity for rapid evolutionary change through epigenetics, selection and drift, and the majority of studies report marked phenotypic change in invasive populations (Garcia-Berthou, 2007; Gozlan et al., 2020; Ribeiro, Elvira, Collares-Pereira, \& Moyel, 2008). Thus, identifying life-history traits that are most relevant for success during different invasion stages is fundamental for understanding the invasion process and for predicting success of new or potential invaders. Successful invaders have traits that promote success at all stages of the invasion process, e.g. Cyprinus carpio and Salmo trutta the widely-distributed species have invasion success presumably resulting from their capacity to adapt to new situations (phenotypic plasticity) rather than to specific life-history attributes (Ribeiro et al., 2008). An invasive species has been reported to exhibit either evolved or plastic adaptations in response to varying environmental conditions in the process of invasion (Garcia-Berthou, 2007; Ribeiro et al., 2008; Vila-Gispert, Alcaraz, \& García-Berthou, 2005). Although invasion success of common carp and tilapia in the Ganga River has been reported to manifest changes in phenotypic, reproductive and trophic characters (Singh et al., 2013), it still has to be investigated for the C. gariepinus, a new species into the river. African catfish introduced to India is deemed as invasive and has gravitated into the Ganga River. Therefore, the morpho-meristic characters, GSI, sex-ratio, maturity stages and the gonadal hormones during the process of invasion of C. gariepinus in the Ganga River were investigated, and the same were compared with those observed in the highly domesticated introduced African catfish available in culture so as to understand whether life-history traits of this fish vary across invasion ranges. Invasion success of the gravitated African catfish into the Ganga River was ascertained based on the plasticity of morpho-meristic, GSI, maturity and gonadal hormones. Further, its potential to breed and expand in the riverine environments was also attempted to be answered considering the morphomeristic and reproductive plasticity.

\section{Methods}

\section{Study area}

Four sampling stations in the districts of Kanpur, Allahabad, Varanasi and Ghazipur of Uttar Pradesh, India, located along the mid-stream of the Ganga River were taken-up for this study (Fig. 1). The specimens of C. gariepinus at the sampling stations were collected with help of fisherfolk by using traps, gill nets and cast nets during 2014 to 2019. African catfish specimens collected from the Ganga River and also from the culture farms located in the cities along the river were brought to the laboratory and identified using taxonomic keys as described by Talwar and Jhingran (1991).

\section{Morphometric-meristic counts}

Detailed morphometric and meristic measurements were studied following the methodology of Talwar and Kacker (1984). A total of 18 morphometric and 5 meristic counts were carefully examined using a digital calliper scale to the nearest precision of $0.01 \mathrm{~mm}$. The conventional method was used to measure the morphometric characters which were the total length (TL), standard length (SL), head depth (HD), body depth at anus (BDA), snout length (SNL), eye diameter (ED), dorsal fin length (DFL), pectoral fin length (PECFL), pelvic fin 


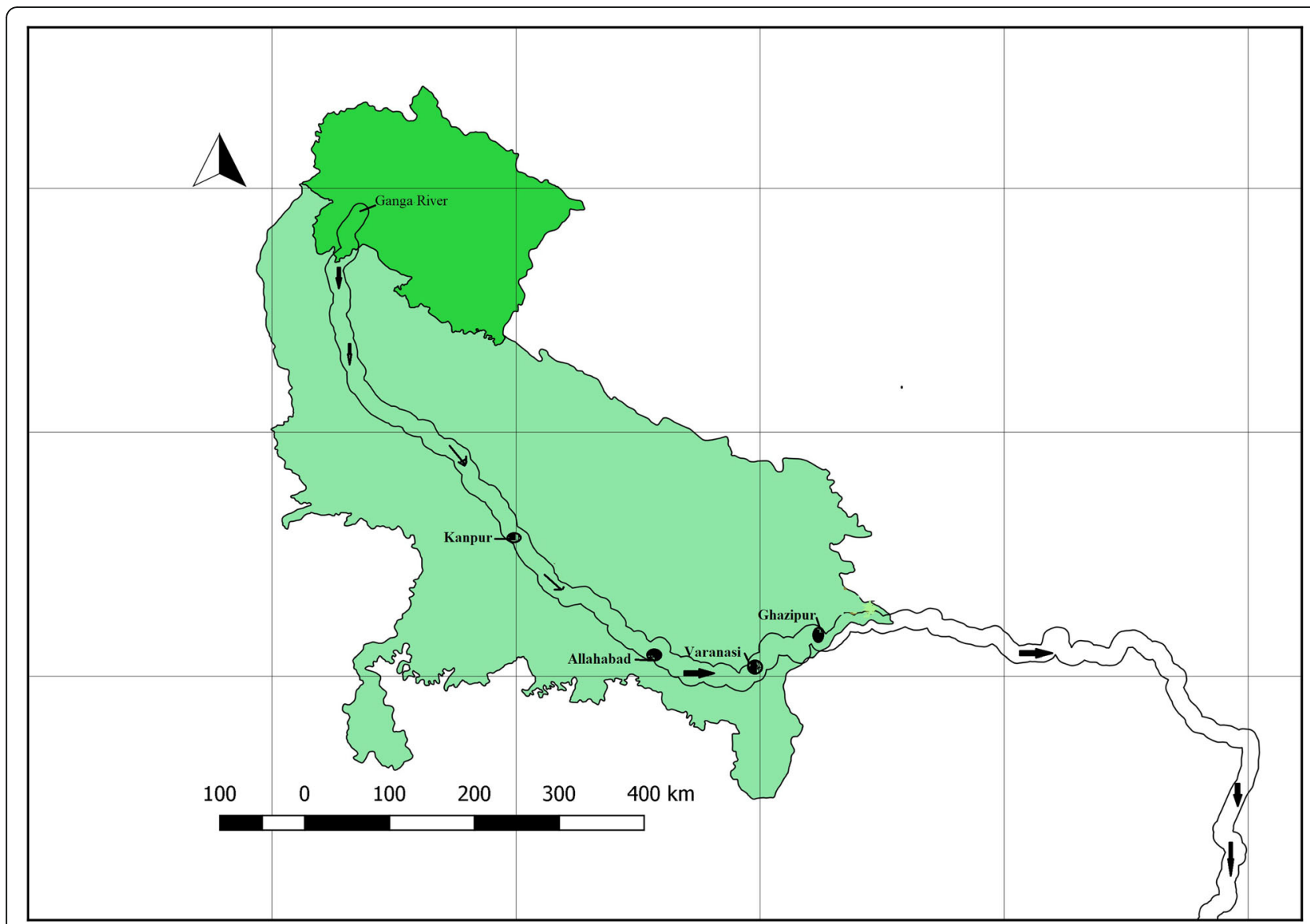

Fig. 1 Map showing sampling locations in the mid-stream of the Ganga River, Uttar Pradesh

length (PELFL), anal fin length (AFL), caudal fin length (CFL), pre-pelvic distance from tip of mouth (PPELD), pre-pectoral distance from tip of mouth (PPECD), preanal distance from tip of mouth (PAD), caudal peduncle (CPD), pectoral spine length (PECSL), head length (HL) and weight $(\mathrm{W})$. The meristic counts examined were dorsal fin rays (DFR), anal fin rays (AFR), pectoral fin rays (PECFR), pelvic fin rays (PELFR) and caudal fin rays (CFR). A magnifying glass was used to count the fin rays, and only the principal rays were counted as separate ray.

\section{Gonadal examinations-macroscopic determination of gonad maturity stages}

The gonads of the collected fish specimens from the Ganga River and also from the culture farms were examined macroscopically for assessing different maturity stages during different seasons in summer (May-June), monsoon (July-August) and winter (Dec-Jan). The gonadosomatic index was further calculated as follows:
Gonadosomatic index (GSI)

$=$ gonad weight/gutted body weight of fish $\times 100$

Fishes were dissected ventrally from the anus to the base of the operculum to reveal the gonad. Gonad maturity stages were assessed visually as immature, developing, ripening, running ripe, fully mature and spent. Based on macroscopic characteristics, certain features were examined to identify the maturity stages. These were the degree of opacity of the gonads, consistency and vascularization, oocytes or sperm visibility and overall colorations of the gonads.

\section{Hormonal estimation}

Blood was collected from the caudal vein and centrifuged at $5000 \mathrm{rpm}$ for $5 \mathrm{~min}$ to separate the serum for assay of estradiol $17-\beta$ and testosterone level with the help of sandwich ELISA kit (Enzo Life Sciences, India). The optical density (OD) of each processed samples was taken at $405 \mathrm{~nm}$. Serum vitellogenin level was assayed using sandwich ELISA kit (Blue Gene Catalogue No 
E10V005C), and the readings were taken at 450-nm wavelength (Singh, 2012). The cross reactivity of the assay and purity was $100 \%$. The sensitivity or limit of detection of the estradiol $17-\beta$ was $14.0 \mathrm{pg} / \mathrm{ml}$.

\section{Statistical analysis}

Non-parametric statistical analysis was used in all the comparisons for morphological data (Zar, 1996). KruskalWallis non-parametric analysis of variance (ANOVA) was used to analyse the differences in morphometric characters and meristic counts of fish (Kruskal \& Wallis, 1952). In the non-parametric test, significant differences between groups were detected using the SPSS (version 16) programme software. An allometric formula of Elliott, Haskard, and Koslow (1995) was used to remove length effects in the samples as per formula $M_{a d j}=M\left(L s / L_{o}\right)^{b}$, where $M$ is the original measurement, $M_{a d j}$ is the sizeadjusted measurement, $\mathrm{L}_{\mathrm{o}}$ is the standard length of fish, and Ls is the overall mean of standard length for all fish samples in each analysis. Parameter b is estimated for each character from the observed data as the slope of the regression of $\log M$ on $\log \mathrm{L}_{\mathrm{o}}$, using all fish in both groups. The efficiency of size adjustment transformations was assessed by testing the significance of correlations between transformed variables and standard length. The linearity of the gonadosomatic index and weight relationship was determined using the equation; $\log \mathrm{Y}=\mathrm{a}+\mathrm{b} \log \mathrm{X}$

where $\mathrm{Y}$ is the gonadosomatic index, $\mathrm{X}$ is the weight of fish ( $\mathrm{g}$ ), and $\mathrm{a}$ and $\mathrm{b}$ are regression constants.

Pearson correlation method and regression coefficient were calculated to test the relationship between reproductive maturity stages with GSI, fish body weight and total length. The observed values of gonadal hormones were expressed as mean \pm standard error (SE), and the statistical significance was determined using Student's ' $\mathrm{t}$ ' test at $5 \%$, and the hormone levels in the specimens in

Table 1 Morphometric and meristic counts (mean \pm SE) of C. gariepinus from culture and captured specimens from the Ganga River

\begin{tabular}{|c|c|c|c|c|c|c|}
\hline & \multirow[t]{2}{*}{ Culture } & \multicolumn{4}{|c|}{ River caught specimens from } & \multirow{2}{*}{$\begin{array}{l}\text { Mean } \pm \text { SE } \\
\text { of I, II, III, IV }\end{array}$} \\
\hline & & I Kanpur & $\begin{array}{l}\text { II } \\
\text { Allahabad }\end{array}$ & $\begin{array}{l}\text { III } \\
\text { Varanasi }\end{array}$ & $\begin{array}{l}\text { IV } \\
\text { Ghazipur }\end{array}$ & \\
\hline \multicolumn{7}{|l|}{ Morphometric parameters (in cm) } \\
\hline Total length (TL) & $50.00 \pm 0.61$ & $42.3-47.0$ & $38.4-48.0$ & $43.7-52.4$ & $11.7-50.7$ & $43.46 \pm 3.12$ \\
\hline Standard length (SL) & $37.08 \pm 1.37$ & $34.6-40.8$ & $33.8-42.3$ & $40.4-48.6$ & $8.6-46.5$ & $38.38 \pm 3.04$ \\
\hline Head depth (HD) & $8.32 \pm 0.09$ & $5.0-7.2$ & $6.3-7.3$ & $7.9-8.4$ & $4.2-8.5$ & $7.05^{*} \pm 0.38$ \\
\hline Body depth at anus (BAD) & $3.58 \pm 0.06$ & $3.5-4.0$ & $3.6-3.9$ & $3.5-3.8$ & $2.4-3.7$ & $3.56 \pm 0.12$ \\
\hline Snout length (SNL) & $4.38 \pm 0.09$ & $2.0-2.8$ & $2.4-3.1$ & $2.8-3.5$ & $1.7-3.4$ & $2.73 \pm 0.16$ \\
\hline Eye diameter (ED) & $1.17 \pm 0.03$ & $1.0-1.2$ & $1.0-1.3$ & $1.0-1.3$ & $0.8-1.3$ & $1.13 \pm 0.04$ \\
\hline Dorsal fin length (DFL) & $28.55 \pm 0.14$ & $19.1-25.8$ & $21.8-26.3$ & $25.4-29.2$ & $5.8-28.8$ & $24.07 \pm 1.87$ \\
\hline Pectoral fin length (PECFL) & $4.78 \pm 0.10$ & $3.5-4.7$ & $3.7-4.4$ & $3.8-4.6$ & $2.4-4.7$ & $4.07 \pm 0.19$ \\
\hline Pelvic fin length (PELFL) & $3.99 \pm 0.11$ & $3.2-3.6$ & $3.1-3.8$ & $3.1-3.6$ & $3-21.2$ & $4.85 \pm 1.49$ \\
\hline Anal fin length (AFL) & $11.63 \pm 0.89$ & $11.5-18.7$ & $15.8-19.4$ & $10.8-11.8$ & $4.1-11.9$ & $13.58 * * \pm 1.32$ \\
\hline Caudal fin length (CFL) & $12.93 \pm 0.79$ & $5.4-10.1$ & $4.6-5.7$ & $3.3-4.1$ & $2.4-4.2$ & $5.02 \pm 0.60$ \\
\hline Pre-pelvic distance from tip of mouth (PPELD) & $20.67 \pm 0.14$ & $14.3-16.8$ & $15.2-17.2$ & $16.4-18.9$ & $4.1-20.1$ & $15.79 \pm 1.15$ \\
\hline Pre-pectoral distance from tip of mouth (PPECD) & $10.48 \pm 0.10$ & $7.4-7.7$ & $7.3-7.5$ & $7.6-9.2$ & $3.2-10.2$ & $7.60 \pm 0.47$ \\
\hline Pre-anal distance from tip of mouth (PAD) & $25.46 \pm 0.13$ & $17.3-20.6$ & $18.9-21.8$ & $21.1-25.6$ & $7.6-26.4$ & $20.39 \pm 1.39$ \\
\hline Caudal peduncle depth (CPD) & $3.76 \pm 0.11$ & $3.0-5.4$ & $4.6-5.7$ & $3.3-4.1$ & $2-4.2$ & $4.18 \pm 0.31$ \\
\hline Pectoral spine length (PECSL) & $3.64 \pm 0.10$ & $2.4-4.1$ & $2.9-4.3$ & $3.4-4.2$ & $2.0-4.7$ & $3.49 \pm 0.24$ \\
\hline Head length $(\mathrm{HL})$ & $12.23 \pm 0.37$ & $10.1-10.3$ & $10.3-11.3$ & $7.2-7.7$ & $2.5-8.2$ & $8.58^{*} \pm 0.71$ \\
\hline Weight (W) g & $953.83 \pm 16.18$ & $430-520$ & $380-670$ & $690-815$ & $170-838$ & $578.42 \pm 59.10$ \\
\hline \multicolumn{7}{|l|}{ Meristic parameters } \\
\hline Dorsal fin rays (DFR) & $71.33 \pm 0.45$ & $70-74$ & $70-73$ & $70-74$ & $70-72$ & $71.42 \pm 0.43$ \\
\hline Anal fin rays (AFR) & $52.42 \pm 0.26$ & $52-54$ & $52-53$ & $51-53$ & $51-53$ & $52.33 \pm 0.26$ \\
\hline Pectoral fin rays (PECFR) & $6.67 \pm 0.31$ & $8-9$ & $8-9$ & $6-8$ & $6-9$ & $7.92^{*} \pm 0.11$ \\
\hline Pelvic fin rays (PELFR) & $6.92 \pm 0.26$ & $6-7$ & $6-8$ & $6-8$ & $6-7$ & $6.67 \pm 0.22$ \\
\hline Caudal fin rays (CFR) & $15.58 \pm 0.23$ & $15-16$ & $15-17$ & $15-17$ & $15-16$ & $15.67 \pm 0.22$ \\
\hline
\end{tabular}


culture and the wild fish examined from the Ganga River at different maturity stages were compared for statistical significance.

\section{Results}

\section{Morphometric and meristic characters}

Observations on African catfish specimens $(n=150)$ from culture farms in the four districts along the Ganga River revealed that there was no significant difference within them with regard to morphometric and meristic counts, reproductive stages, GSI and gonadal hormones. However, morpho-meristic characters recorded from 97 specimens of size 11.7 to $52.4 \mathrm{~cm}$ (mean $43.46 \pm 3.12$ ) and weighing 170 to $838 \mathrm{~g}$ (mean $578.42 \pm 59.10 \mathrm{~g}$ ) captured in the Ganga River when compared with those from culture revealed that most of the morphometric and meristic measurements did not show significant differences except four characters, the HD, HL, PECFR and AFL (Table 1). Kruskal-Wallis non-parametric analysis of variance showed that there were significant $(p<0.05)$ linear correlations between $\mathrm{HD}, \mathrm{HL}$ and PECFR in fish specimens from culture and river-captured specimens while the significance level for AFL was $p<0.01$. The efficiency of size adjustment transformations was assessed by testing the significance of correlations between transformed variables and standard length as per allometric formula. The correlation coefficient ' $\mathrm{r}$ ' between $\log$ length and $\log$ weight was found to be 0.9690 and 0.8754 in culture and river-caught specimens respectively.

\section{Gonadal examinations-macroscopic determination of gonad maturity stages}

Macroscopic examination classifying maturity stages in C. gariepinus revealed presence of distinct gonadal conditions as immature, developing, ripening, running ripe, fully mature and spent. The detailed anatomical features examined macroscopically for determining reproductive phases of both the sexes in culture specimens are presented (Table 2). Based on the macroscopic assessment of the testes and ovary, no abnormalities were observed in the river-caught specimens, providing an initial indication that the testes and ovaries were in good health. The mean temperature at culture farms in summer was $29.7 \pm 1.43$, in monsoon $27.8 \pm 1.32$ and in winters $19.8 \pm$ 1.29 respectively during which the gonads developed in the fish. While the mean temperature in the Ganga River at Kanpur, Allahabad, Varanasi and Ghazipur was 26.6 0.79 during summer, $23.8 \pm 1.02 \pm 0.79$ during monsoon and $17.2 \pm 0.58$ during winter respectively. However, there was wide variation in the frequency occurrences of maturity stages in river-caught male C. gariepinus when compared to fish specimens from culture farms (Fig. 2). The frequency occurrence of stage IV maturity in males was $33.85 \%$, and in females, it was $27.36 \%$ under culture in summer. In monsoon, $27.78 \%$ males and $19.20 \% \mathrm{fe}-$ males were found of stage IV maturity stage in culture. However, the stage IV maturity level in males was even larger in river-caught specimens where it was $58.48 \%$ in summer and $61.46 \%$ in monsoon respectively (Fig. 2). Similarly, the frequency occurrence of stage IV maturity in females captured from the river was found largest in summer where it was $55.46 \%$ followed by monsoon, and it was $53.48 \%$ (Fig. 3). In monsoon, the largest maturity frequency for stage $\mathrm{V}$ was $28.89 \%$ for males under culture while in river-caught specimens it was $6.24 \%$ in the same season. The stage V gonadal maturity for females captured from the river was $15.27 \%$ during monsoon while in specimens from culture it was $12.75 \%$. In winter also, we could observe that as high as $66.28 \%$ males captured from the river were of stage IV gonadal maturity while under culture the maturity percent for stage IV

Table 2 Macroscopically classified reproductive stages in C. gariepinus based on maturity scale

\begin{tabular}{|c|c|c|}
\hline \multirow{2}{*}{$\begin{array}{l}\text { Maturity } \\
\text { stages }\end{array}$} & \multicolumn{2}{|l|}{ Description of maturity stages } \\
\hline & Males & Females \\
\hline I (immature) & $\begin{array}{l}\text { A pair of thin thread like gonads, sexes at early } \\
\text { stage were indistinguishable macroscopically. }\end{array}$ & $\begin{array}{l}\text { A pair of thin thread-like gonads, sexes at early stage were indistinguishable } \\
\text { macroscopically. }\end{array}$ \\
\hline 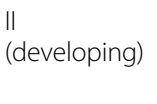 & Testes semi-transparent and flattened & $\begin{array}{l}\text { Ovary reddish, smooth, small ova were hardly visible in transparent matrix of } \\
\text { follicular cells. Ova volumes are smaller than matrix and exuded when lobes were } \\
\text { cut and squeezed. }\end{array}$ \\
\hline III (ripening) & $\begin{array}{l}\text { Testes whitish, wide and more or less flattened. No } \\
\text { milt exuded when cut or squeezed }\end{array}$ & $\begin{array}{l}\text { Ovary opaque and yellowish; small or visible in transparent matrix of follicular } \\
\text { cells. }\end{array}$ \\
\hline $\begin{array}{l}\text { IV (running } \\
\text { ripe) }\end{array}$ & $\begin{array}{l}\text { Testes with firm clear lobes less flattened. Small } \\
\text { amount of milt present }\end{array}$ & $\begin{array}{l}\text { Ovary yellowish, fully swollen with translucent yellow ova. Pre-mature ova volume } \\
\text { larger than matrix. }\end{array}$ \\
\hline $\begin{array}{l}V \text { (fully } \\
\text { mature) }\end{array}$ & $\begin{array}{l}\text { Testes with fully developed lobes. Readily } \\
\text { produced milt when lobes were cut and squeezed. }\end{array}$ & $\begin{array}{l}\text { Ovary yellowish very soft and swollen. Greenish yellow ova were visible through } \\
\text { superficial membranes, and ova were tightly packed. Little follicular matrix was } \\
\text { present. Ova extruded when pressure applied on vent }\end{array}$ \\
\hline VI (spent) & $\begin{array}{l}\text { Testes flattened having thin lobes but milt did not } \\
\text { extrude when cut and squeezed }\end{array}$ & $\begin{array}{l}\text { Ova did not extrude from vent when pressure was applied from pectoral fin to } \\
\text { vent. }\end{array}$ \\
\hline
\end{tabular}




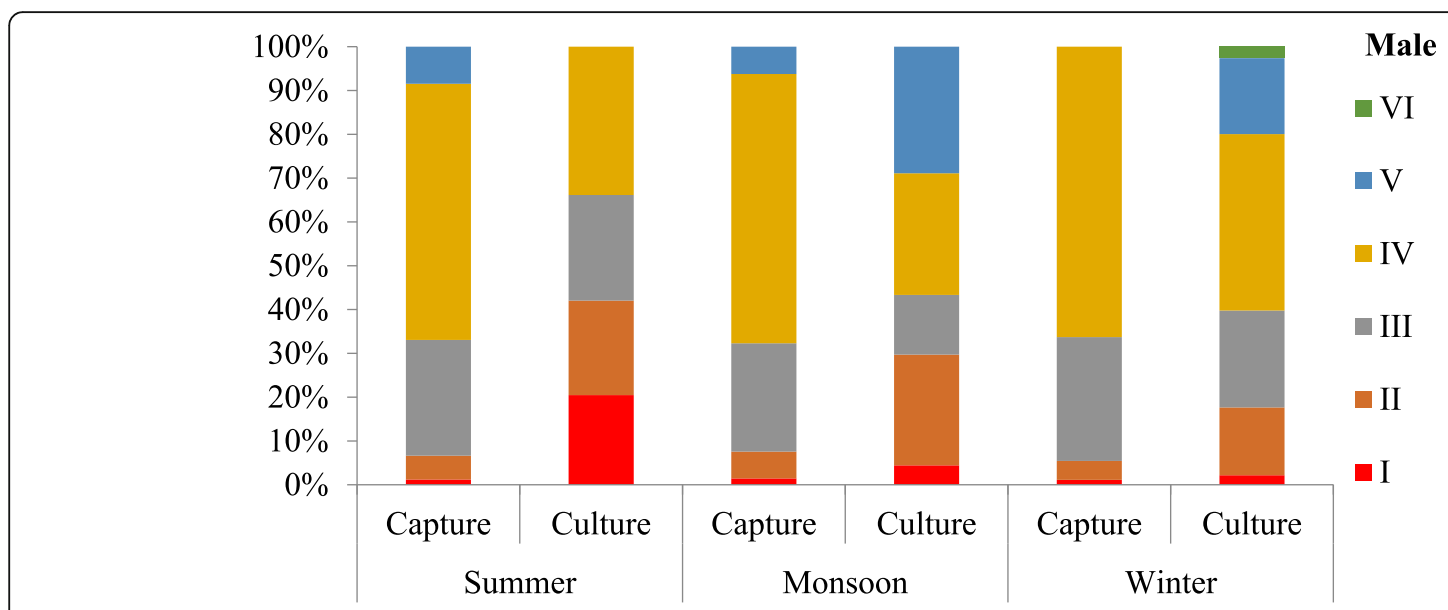

Fig. 2 Seasonal changes in the percent frequency of the maturity stages of male C. gariepinus from culture and the Ganga River (maturity stages: I-immature, II-developing, III-ripening, IV-running ripe, V-fully mature, VI-spent)

males was merely $40.26 \%$. There was also presence of $57.54 \%$ females of stage IV in the river while under culture largest maturity frequency was of $32.48 \%$ for females (Fig. 3). In river, we did not record any male or female C. gariepinus attaining stage V maturity during winter while $17.34 \%$ males and $4.59 \%$ females of stage $\mathrm{V}$ were recorded under culture in the same season.

The seasonal variations in mean gonadosomatic index (GSI) of the male and female C. gariepinus are presented in Table 3. The mean GSI of male fish in culture during summer was $0.64 \pm 0.24$ while in case of male specimens captured from the Ganga River at Kanpur it was 0.26 \pm 0.03 , Allahabad $0.21 \pm 0.01$, Varanasi $0.72 \pm 0.33$ and Ghazipur $0.22 \pm 0.02$ respectively. The highest value of GSI was found in female C. gariepinus specimens captured in the Ganga River at Varanasi during monsoon season. The mean GSI of females in summer was $16.67 \pm 5.81$ in culture, and it was $0.79 \pm 0.31$ at Kanpur, $2.3 \pm 0.13$ at Allahabad, $4.6 \pm 0.21$ at Varanasi and $5.5 \pm 0.3$ at Ghazipur in the specimens captured from the Ganga River (Table 3). During monsoon and winter, the mean GSI of males in culture was $0.77 \pm 0.41$ and $0.37 \pm 0.02$ respectively while in females it was $15.95 \pm 3.24$ and $8.54 \pm 2.3$ respectively. The linearity of the gonadosomatic index and weight relationship showed a statistical significance $(p<0.05)$ in specimens collected from the Ganga River. For both sexes, the $r$ values indicated highest correlation between GSI and gonad maturation stage, followed by GSI and

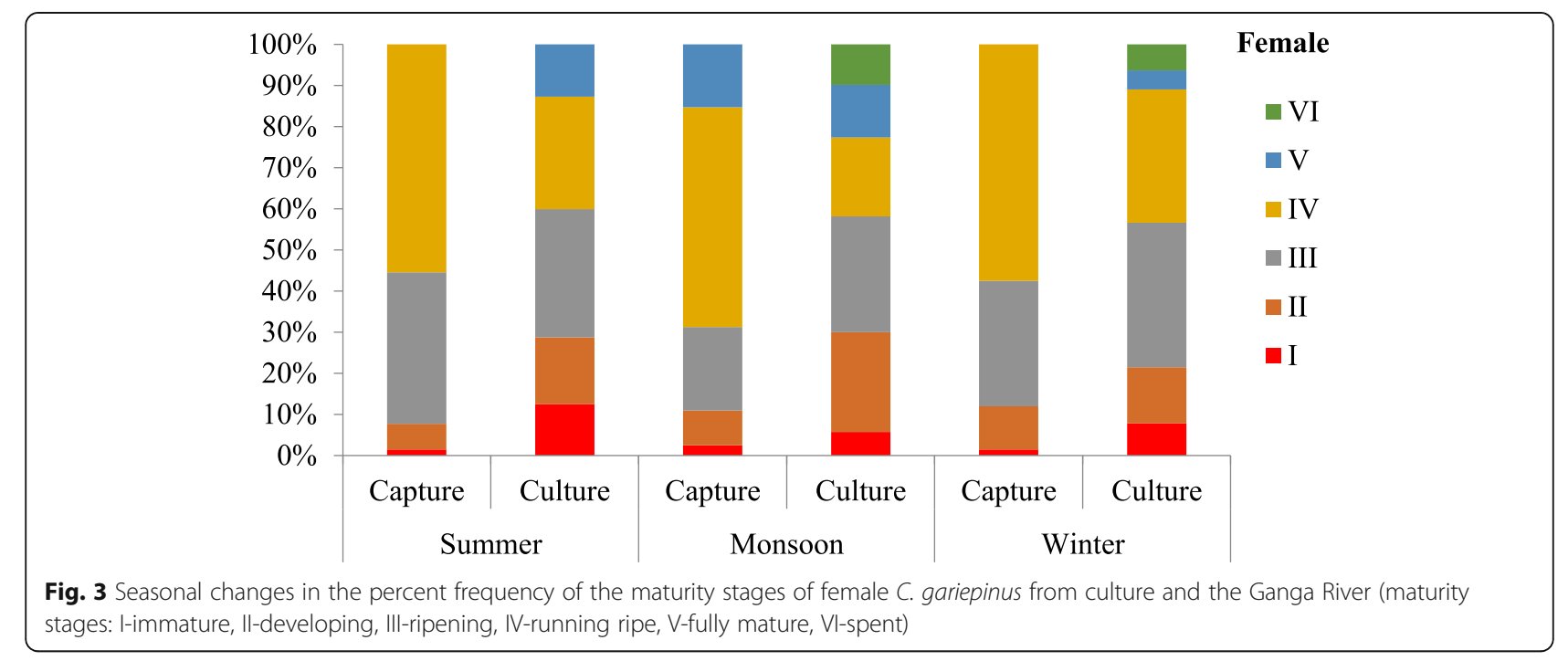


Table 3 Seasonal variation of GSI (mean \pm SE) of C. gariepinus captured from the Ganga River

\begin{tabular}{|c|c|c|c|c|c|c|}
\hline \multirow[t]{2}{*}{ Sites } & \multicolumn{2}{|l|}{ Summer } & \multicolumn{2}{|l|}{ Monsoon } & \multicolumn{2}{|l|}{ Winter } \\
\hline & $\overline{\mathrm{GSI} \text { (male) }}$ & $\overline{\text { GSI (female) }}$ & $\overline{\text { GSI (male) }}$ & $\overline{\text { GSI (female) }}$ & GSI (male) & $\overline{\text { GSI (female) }}$ \\
\hline Kanpur & $0.26 \pm 0.03$ & $0.79 \pm 0.31$ & $0.62 \pm 0.11$ & $1.8 \pm 0.34$ & $0.59 \pm 0.03$ & $1.46 \pm 0.10$ \\
\hline Allahabad & $0.21 \pm 0.01$ & $2.3 \pm 0.13$ & $0.81 \pm 0.33$ & $11.2 \pm 0.43$ & $0.43 \pm 0.03$ & $3.8 \pm 0.03$ \\
\hline Varanasi & $0.72 \pm 0.33$ & $4.6 \pm 0.21$ & $0.59 \pm 0.13$ & $17.8 \pm 0.53$ & $0.71 \pm 0.13$ & $4.5 \pm 0.05$ \\
\hline Ghazipur & $0.22 \pm 0.02$ & $5.5 \pm 0.30$ & $0.31 \pm 0.01$ & $6.2 \pm 0.53$ & $0.92 \pm 0.13$ & $3.2 \pm 0.23$ \\
\hline
\end{tabular}

total weight (TW), while the lowest correlation was between GSI and TL in the river-caught specimens. Regression analysis indicated a positive correlation between river condition and the GSI $(r=0.86)$ as well as between captive condition and the GSI $(r=0.90)$.

The observations on the sex ratio of $C$. gariepinus in mid-stream of the Ganga River revealed seasonal variations in abundance of male and female individuals of $C$. gariepinus. Chi-square $\left(x^{2}\right)$ analysis of male to female sex-ratio was determined by multiple regression analysis. The results showed that sex-ratio distribution varied greatly from the expected 1male: 1 female with respect to season, with an overall sex ratio of 3:2 (male: female). However, the differences were not significant $\left(\chi^{2}=0.48\right.$; $\mathrm{df}=1 ; P>0.05 ; \chi^{2}=0.65 ; \mathrm{df}=1 ; P>0.05 ; \chi^{2}=0.94 ; \mathrm{df}=$ $1 ; P>0.01)$ during different seasons.

\section{Hormonal estimations}

The serum testosterone, estradiol-17 $\beta$ and vitellogenin hormones in $C$. gariepinus specimens captured from the Ganga River were estimated in 10 pooled specimens of each reproductive stages, and the same was compared with the corresponding reproductive stages in culture specimens (Fig. 4). The mean value of serum testosterone was lowest $9.58 \pm 1.64 \mathrm{pg} / \mathrm{ml}$ in gonadal maturity stage I male specimens of $C$. gariepinus captured from the river while the corresponding testosterone level in the culture specimens of maturity stage I was $18.58 \pm 1.14 \mathrm{pg} / \mathrm{ml}$. At the same time, highest level of testosterone was found in stage $\mathrm{V}$ which was $184.82 \pm 10.4 \mathrm{pg} / \mathrm{ml}$ in culture and $204.82 \pm 21.34 \mathrm{pg} / \mathrm{ml}$ in captured male specimens from the river showing a significant $(p<0.05)$ variation (Fig. 4$)$. In case of female $C$. gariepinus, the mean value of serum estradiol- $17 \beta$ was lowest $(67.25 \pm 11.4 \mathrm{pg} / \mathrm{ml})$ in maturity stage I and highest $(328.73 \pm 24.5 \mathrm{pg} / \mathrm{ml})$ in maturity stage $\mathrm{V}$ in the river-captured fish. However, the corresponding values of serum estradiol- $17 \beta$ in the cultured $C$. gariepinus of the same reproductive stages was higher and statistically significant $(p<0.05)$ than what we observed in the river-captured fish (Fig. 5). We did not observe any vitellogenin level in maturity stages I and II in females either in culture or in captured specimens from the Ganga River. However, vitellogenin level in female $C$. gariepinus was found in gonadal stage III where it was $8.64 \pm 01.12 \mathrm{pg} / \mathrm{ml}$

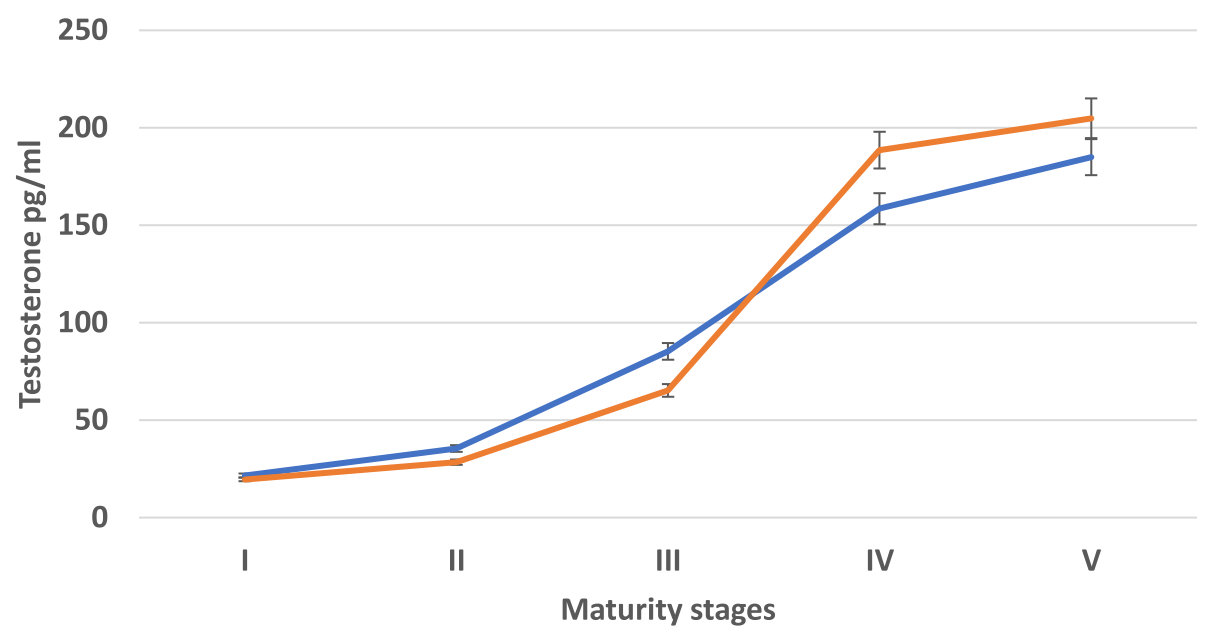

-Male Culture -Male Capture

Fig. 4 Testosterone level of male C. gariepinus in different reproductive stages from culture and the Ganga River (maturity stages: I-immature, IIdeveloping, II-ripening, IV-running ripe, V-fully mature) 


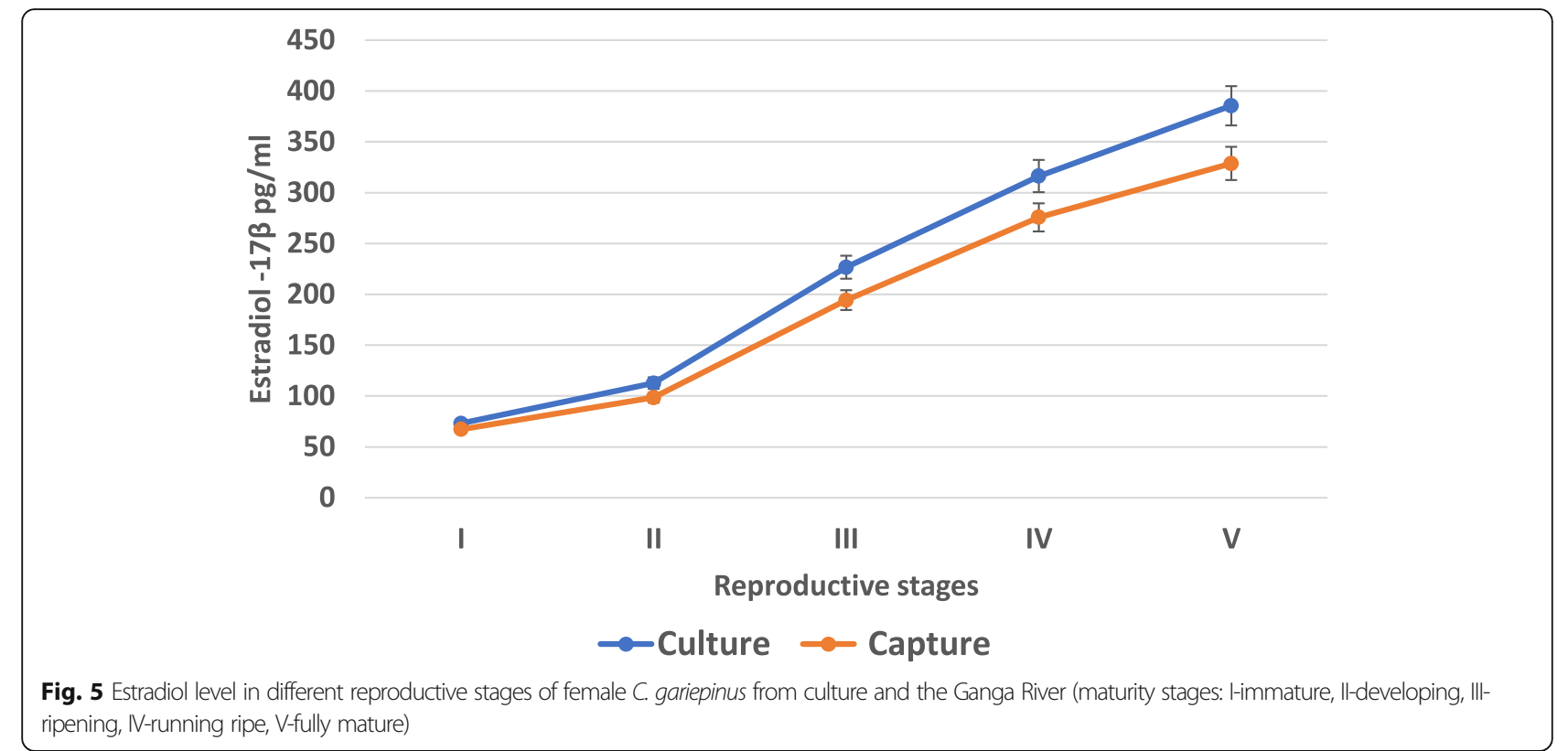

in captured fishes from the Ganga River and $5.24 \pm 0.22$ $\mathrm{pg} / \mathrm{ml}$ in fish available in culture. Maximum level of vitellogenin was observed in stage $\mathrm{V}$ where it was $16.68 \pm$ $2.98 \mathrm{pg} / \mathrm{ml}$ in river-captured specimens and $12.63 \pm 2.12$ $\mathrm{pg} / \mathrm{ml}$ in culture specimens, and the difference was statistically significant $(p<0.05)$ (Fig. 6).

\section{Discussion}

A total of 23 morpho-meristic characters of C. gariepinus specimens collected from culture farms when compared with the fish specimens captured in the Ganga river has shown a very interesting information that four morpho-meristic characters, namely the head length (HL), head depth (HD), pectoral fin rays (PECFR) and anal fin length (AFL), have been significantly different. The findings of this study have evaluated morpho-meristic differences between river and cultured African catfish highlighting the adaptive processes of invasive C. gariepinus on account of variations of environments in captivity and the Ganga River. The results of this study corroborate with earlier reports where morphometric and meristic variables have been used to quantify biological variation and identify and explain adaptive processes of different

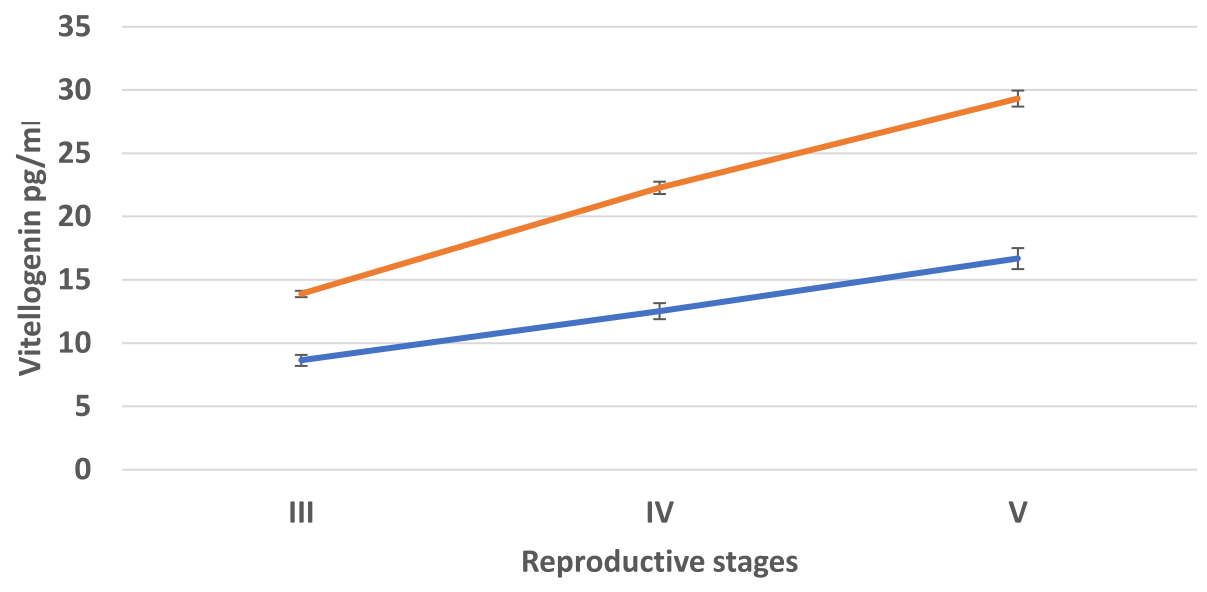
IV-running ripe)

- Culture - Capture

Fig. 6 Vitellogenin level in different reproductive stages of female C. gariepinus from culture and the Ganga River (maturity stages: III-ripening, 
populations of the same species (Gonzalez et al., 2016; Madhusoodanan et al., 2016; Solomon, Okomoda, \& Ogbenyikwu, 2015). The variations in morpho-meristic characters in C. gariepinus under captivity and the Ganga River could have been due to differences in the food abundance, water quality, temperature and rainfall (Ezeafulukwe, Njoku, Ekeledo, \& Adaka, 2015; Fagbuaro, Oso, Olurotimi, \& Akinyemi, 2015; Tawwab, 2005; Turan, Sukran, Turan, Okur, \& Akyurt, 2005). Water temperature is considered as one of the most important factors determining fish dispersal by directly affecting body metabolism and behaviours, development, growth and breeding (Buisson, Thuiller, Lek, Lim, \& Grenouillet, 2008). The significant phenotype plasticity might be associated with the fitness of the African catfish in the riverine water conditions allowing it for successful invasion and survival as it is reported that phenotypic plasticity enables an invasive species to colonise and to cope with novel environmental conditions (Davidson, Jennion, \& Nicotra, 2011; Madhusoodanan et al., 2016; Singh et al., 2013). The findings of this study on the ability of African catfish to cope up with environmental fluctuations from culture to riverine conditions has been considered as adaptive phenotypic plasticity which is likely to affect not only its ability to become established but also to outcompete the existing native fish species, i.e. its success as an invader (Davidson et al., 2011; Ranjan, 2018; Singh et al., 2013). It is pertinent to mention here that African catfish is highly carnivorous and has been reported to adversely affect the existence of even endemic fishes (Ranjan, 2018; Singh, Ansari, Srivastava, \& Shrivastava, 2015).

Reproductive plasticity is another key determinant of species invasiveness (Tucker, Zurliene, Suski, \& Nowak, 2020) which is addressed here in this study pertaining to invasion success of African catfish in the Ganga River. We have investigated that the reproductive stages of $C$. gariepinus collected from the Ganga River have differed from the maturity stages observed in the culture. The GSI of C. gariepinus has also been observed to reveal a distinct deviation from culture to river-caught fish. This kind of variation in reproductive stages and GSI of male and female specimens under culture and in the Ganga River could be attributable to artificial feeding provided to the fish in culture as the gonadal maturity is dependent on the food available to the fish and also on the environmental conditions (Davidson et al., 2011). However, sexual maturity in C. gariepinus under captivity has been found to display variations in the reproductive development from that of riverine habitat of the Ganga (Singh et al., 2015). The river-caught C. gariepinus has been found to mature at an age of about 12 months and above when they attained larger size (Yalcin, Solar, \& Akyurt, 2001) while C. gariepinus in culture has been found to mature just in 6 to 7 months of age (Singh et al., 2015). The GSI of male and female fish captured from the Ganga in Varanasi was higher as compared to corresponding culture specimens. The findings of this study on changes in GSI are corroborated with higher testosterone level in males and serum estradiol- $17 \beta$ in females captured in the river. The maturity stages in river-caught specimens were different from what was found under culture. Similarly, both testosterone and estradiol-17 $\beta$ levels also were found higher in river-caught male and female specimens respectively. The estradiol-17 $\beta$ level in stage $\mathrm{V}$ maturity in female $C$. gariepinus captured from the Ganga River was highest. At the same time, maximum level of vitellogenin was also observed in maturity stage $\mathrm{V}$ in specimens captured from the river indicating that there exists strong breeding potential in C. gariepinus in the river. All these findings strongly point out that the invading African catfish have strong breeding potential in the Ganga River particularly in the Varanasi and Allahabad stretch. The elicited reproductive plasticity in C. gariepinus that invaded into the Ganga further delineates that the fish is increasing its fitness in a given environment of the Ganga River at Varanasi and Allahabad (Davidson et al., 2011; Singh et al., 2013). The findings of this study further display adaptations of the African catfish for reproductive performance even in a changed environment of the Ganga River from that of captive conditions. Therefore, the reproductive plasticity vs. adaptation of the invasive African catfish is considered as indicators of colonisation and spread since the fish inhabits varying environmental conditions from one location to another even in different rivers, i.e. the Yamuna River, Godavari and the Ganga River (Ranjan, 2018; Singh, 2014; Singh et al., 2013; Singh et al., 2015; Singh \& Lakra, 2011). It is expected that the reproductive plasticity may also increase the ability of $C$. gariepinus to cope up with unpredictable environments. We have observed an association between the plasma level estradiol-17 $\beta$ and vitellogenin displaying reproductive activities under controlled condition in culture and confirming the possibility of breeding in riverine conditions at the same time. There are trade-offs between reproductive hormones (the testosterone, estradiol-17 $\beta$ and vitellogenin) and dispersal of African catfish in the Ganga River which is important to understanding the expected spread of this new invasive fish to the Ganga River. It is, thus, understanding key traits that predict or enhance if invasion success is critical for the implementation of management and control actions. In fact, the findings of this study on the changes in the morphometric-meristic characters, maturity and gonadal hormones provide first clue into the invasion success of 
the African catfish into the Ganga River. Adaptive plasticity of the African catfish has further allowed it to survive novel environments of the river. The adaptive morpho-meristic changes and the reproductive plasticity exhibit the driving force behind the invasion success of the fish. The knowledge generated on the phenotypic and reproductive plasticity towards adaptation of African catfish gravitated into the Ganga River will help management and control programmes.

\section{Conclusion}

Our results suggest that phenotypic and reproductive characteristics of African catfish facilitate successful transition between invasion stages in the Ganga River. Based on the results recorded on the plasticity of lifehistory traits particularly the morpho-metrics and reproductive parameters, the African catfish have been found to exist into the Ganga River from Kanpur to Ghazipur in Uttar Pradesh. The success or failure of invasion event apparently depends not only on the observed biological attributes of the invader but also on the recipient habitat characteristics, including both biotic and abiotic factors. It pointed out that tolerance of the environmental factors such as flow, temperature, food items and other local biotic and abiotic conditions have been allowing African catfish to colonise new areas in the Ganga River besides the plasticity in life-history characters (Singh et al., 2013) and ultimately expanding their distribution ranges. Our results, thus, simultaneously indicate that distribution of introduced African catfish is likely to be affected by a change of climate, and the fish will display a substantial ability to quickly adapt to the environmental changes and the effects of climate change. Understanding the factors leading to successful invasions is of great practical and conceptual importance. From a practical point of view, it should help to prevent future invasions and to mitigate the effects of recent invaders through early detection and the prioritisation of management measures.

\section{Abbreviations \\ TL: Total length; SL: Standard length; HD: Head depth; BDA: Body depth at anus; SNL: Snout length; ED: Eye diameter; DFL: Dorsal fin length; PECF L: Pectoral fin length; PELFL: Pelvic fin length; AFL: Anal fin length; CFL: Caudal fin length; PPELD: Pre-pelvic distance from tip of mouth; PPEC D: Pre-pectoral distance from tip of mouth; PAD: Pre-anal distance from tip of mouth; CPD: Caudal peduncle; PECSL: Pectoral spine length; HL: Head length; W: Weight; DFR: Dorsal fin rays; AFR: Anal fin rays; PECFR: Pectoral fin rays; PELFR: Pelvic fin rays; CFR: Caudal fin rays; GSI: Gonadosomatic index}

\section{Acknowledgements}

The authors are thankful to the fisherman societies involved in regular fishing along Ganga for sharing their catch information during the study period of study and providing fish specimens for our research work.

\section{Authors' contributions}

AS/AA/SS designed, carried out the study and analysed the field and laboratory data. SS worked for the statistical analysis. AA was involved in the laboratory work analysis and field work and was supervised by AS. The authors read and approved the final manuscript.

\section{Funding}

Not applicable.

\section{Availability of data and materials}

Not applicable.

\section{Declarations}

Ethics approval and consent to participate

Not applicable.

\section{Consent for publication}

Not applicable.

\section{Competing interests}

The authors declare that they have no competing interests.

Received: 26 August 2020 Accepted: 10 May 2021

Published online: 25 May 2021

\section{References}

Blackburn, T. M., Pysek, P., Bacher, S., Carlton, J. T., Duncan, R. P., Jarosik, V., Richardson David, M. (2011). A proposed unified framework for biological invasions. Trends in Ecology \& Evolution, 26(7), 333-339. https://doi.org/10.101 6/j.tree.2011.03.023

Buisson, L., Thuiller, W., Lek, S., Lim, P., \& Grenouillet, G. (2008). Climate change hastens the turnover of stream fish assemblages. Global Change Biology, 14(10), 2232-2248. https://doi.org/10.1111/j.1365-2486.2008.01657.x.

Das, M. K., Sharma, A. P., Vass, K. K., Tyagi, R. K., Suresh, V. R., Naskar, M., \& Akolkar, A. B. (2013). Fish diversity, community structure and ecological integrity of the tropical River Ganges, India. Aquatic Ecosystem Health \& Management, 16(4), 395-407. https://doi.org/10.1080/14634988.2013.851592.

Davidson, A. M., Jennion, M., \& Nicotra, A. B. (2011). Do invasive species show higher phenotypic plasticity than native species and, if so, is it adaptive? A meta-analysis. Ecology Letters, 14(4), 419-431. https://doi.org/10.1111/j.14610248.2011.01596.x.

Elliott, N. G., Haskard, K., \& Koslow, J. A. (1995). Morphometric analysis of orange roughy (Hoplostethus atlanticus) off the continental slope of southern Australia. Journal of Fish Biology First published: February 1995, 46, 202-220. https://doi.org/10.1111/j.1095-8649.1995.tb05962.x.

Ezeafulukwe, C. F., Njoku, D. C., Ekeledo, C. B., \& Adaka, G. S. (2015). Morphomeristic characteristics of selected cichlid fishes from two aquatic environments in Imo state, Nigeria. International Journal of Veterinary Science, 4(3), 131-135.

Fagbuaro, O., Oso, J. A., Olurotimi, M. B., \& Akinyemi, O. (2015). Morphometric and meristic characteristics of Clarias gariepinus from controlled and uncontrolled population from southwestern Nigeria. Journal of Agriculture and Ecology Research International, 2(1), 39-45. https://doi.org/10.9734/JAERI/2015/11781.

FAO (2016). Cultured Aquatic Species Information Programme: Clarias gariepinus. Fisheries and Aquaculture Department, Food and Agricultural Organization of the United Nations, Rome.

Garcia-Berthou, E. (2007). The characteristics of invasive fishes: what has been learned so far? Journal of Fish Biology, 71(Special Issue D), 33-55. First published: 12 December 2007. https://doi.org/10.1111/j.1095-8649.2007.01668.x.

Gonzalez, M. A., Rodriguez, J. M., Angon, E., Martinez, A., Garcia, A., \& Pena, F. (2016). Characterization of morphological and meristic traits and their variations between two different populations (wild and cultured) of Cichlasoma festae, a species native to tropical Ecuadorian rivers. Archiv fur Tierzucht, 59(4), 435-444. https://doi.org/10.5194/aab-59-435-2016.

Gozlan, R. E., Zahorska, E., Cherif, E., Asaeda, T., Britton, J. R., Chang, C., ... Combe, M. (2020). Native drivers of fish life history traits are lost during the invasion process. Ecology and Evolution, 10(16), 8623-8633. https://doi.org/10.1002/ ece3.6521.

Gu, D. H., Xu, Y.-C., Wei, M., Luo, H., Yang, D., Yu, Y., .. X. (2017). Fish invasion in the river systems of Guangdong Province, South China: Possible indicators of their success. Fisheries Management and Ecology, 25. https://doi.org/10.1111/ fme. 12265 . 
Krishnakumar, K., Ali, A., Pereira, B., \& Raghavan, R. (2011). Unregulated aquaculture and invasive alien species: A case study of the African catfish Clarias gariepinus in Vembenad Lake (Ramsar Wetland), Kerala. Indian Journal of Threatened Taxa, 3(5), 1737-1744. https://doi.org/10.11609/JoTT.02378.1737-44.

Kruskal, W. S., \& Wallis, W. A. (1952). Use of ranks in one criterion variance analysis. Journal of the American statistical Association, 47(260), 583-621. https://doi. org/10.1080/01621459.1952.10483441.

Madhusoodanan, P. P., Prasannan, K., Smrithy, R., \& Biju Kumar, A. (2016). Lengthweight relationship and condition factors of the African catfish, Clarias gariepinus (Burchell, 1822) in Mattupetty reservoir, southern Western Ghats, Kerala, India. Journal of Aquatic Biology \& Fisheries, 4, 81-88 ISSN 2321-340X.

Ranjan, R. (2018). Protecting endemic species from African catfish invasion when community behavioral responses get in the way. PLoS One, 13(12), e0209009. https://doi.org/10.1371/journal.pone.0209009.

Ribeiro, F., Elvira, B., Collares-Pereira, M. J., \& Moyel, P. B. (2008). Life-history traits of non-native fishes in Iberian watersheds across several invasion stages: A first approach. Biological Invasions, 10(1), 89-102. https://doi.org/10.1007/s1 0530-007-9112-2.

Sarkar, U. K., Dubey, V. K., Singh, S. P., \& Singh, A. K. (2017). Employing indicators for prioritization of fish assemblage with a view to manage freshwater fish diversity and ecosystem health in the tributaries of Ganges basin, India. Aquatic Ecosystem Health and Management, 20(1-2), 21-29. https://doi.org/1 0.1080/14634988.2017.1270146.

Singh, A. K. (2012). Introduction of modern endocrine techniques for the production of monosex population of fishes. General and Comparative Endocrinology, 181, 146-155.

Singh, A. K. (2014). Emerging alien species in Indian aquaculture: prospects and threats. Journal of Aquatic Biology \& Fisheries, 2(1), 32-41 @ Department of Aquatic Biology \& Fisheries, University of Kerala.

Singh, A. K., Ansari, A., Srivastava, S. C., \& Shrivastava, V. K. (2015). An appraisal of introduced African catfish Clarias gariepinus (Burchell 1822) in India: Invasion and risks. Annual Research \& Review in Biology, 6(1), 41-58. https://doi.org/10. 9734/ARRB/2015/13375.

Singh, A. K., Kumar, D., Srivastava, S. C., Ansari, A., Jena, J. K., \& Sarkar, U. K. (2013). Invasion and impacts of alien fish species in the Ganga river, India. Aquatic Ecosystem Health \& Management, 16, 1-7.

Singh, A. K., \& Lakra, W. S. (2011). Risk and benefit assessment of alien fish species of the aquaculture and aquarium trade into India. Reviews in Aquaculture, 3(1), 3-18. https://doi.org/10.1111/j.1753-5131.2010.01039.x.

Singh, A. K., Srivastava, S. C., Ansari, A., Kumar, D., \& Singh, R. (2012). Environmental monitoring and risk assessment of African catfish Clariasgariepinus (Burchell 1822) cultured in Rural Ponds, India. Bulletin of Environmental Contamination and Toxicology, 89, 1142-1147. https://doi.org/1 0.1007/s00128-012-0860-z Springer.

Solomon, S. O., Okomoda, V. T., \& Ogbenyikwu, A. I. (2015). Intraspecific morphological variation between cultured and wild Clarias gariepinus (Burchell) (Clariidae, Siluriformes). Archives of Polish Fisheries, 23(1), 53-61. https://doi.org/10.1515/aopf-2015-0006.

Talwar, P. K., \& Jhingran, A. G. (1991). Inland fishes of India and adjacent countries, (vol. 1 \& 2). Oxford \& IBH Publishing Co. Pvt. Ltd.

Talwar, P. K., \& Kacker, R. K. (1984). Commercial sea fishes of India. Zoological Survey of India, Calcutta, (p. 997).

Tawwab, M. A. (2005). Predation efficiency of Nile catfish Clarias gariepinus (Burchell, 1822) on fry of Nile tilapia Oreochromis niloticus (Linnaeus, 1758): Effects of prey density, predator size feed supplementation and submerged vegetation. Turkish Journal of Fisheries and Aquatic Sciences, 5, 69-74.

Tucker, E. K., Zurliene, M. E., Suski, C. D., \& Nowak, R. A. (2020). Gonad development and reproductive hormones of invasive silver carp (Hypophthalmichthys molitrix) in the Illinois River. Biology of Reproduction, 102(3), 647-659. https://doi.org/10.1093/biolre/ioz207.

Turan, Cemal; Sukran, Yalçin; Turan, Funda; Okur, Emel \& Akyurt, Ihsan (2005). Morphometric comparisons of African catfish, Clarias gariepinus, populations in Turkey. Folia Zoologica, Praha 54(1/2), 165-172.

Vila-Gispert, A., Alcaraz, C., \& García-Berthou, E. (2005). Life-history traits of invasive fish in small Mediterranean streams. Biological Invasions, 7(1), 107-116. https://doi.org/10.1007/s10530-004-9640-y.

Yalcin, S., Solar, K., \& Akyurt, I. (2001). Certain reproductive characteristics of the catfish (Clarias gariepinus Burchell, 1822) living in the River Asi, Turkey. Turkish Journal of Zoology, 25, 453-460.

Zar, J. A. (1996). Biostatistical analyses, (3rd ed., p. 156). Prentice Hall.

\section{Publisher's Note}

Springer Nature remains neutral with regard to jurisdictional claims in published maps and institutional affiliations.

\section{Submit your manuscript to a SpringerOpen ${ }^{\circ}$ journal and benefit from:}

- Convenient online submission

- Rigorous peer review

- Open access: articles freely available online

- High visibility within the field

- Retaining the copyright to your article

Submit your next manuscript at $\boldsymbol{\nabla}$ springeropen.com 